\title{
The Effect of Creative Drama as a Method on Skills: A Meta-analysis Study
}

\author{
Özgür Ulubey \\ Correspondence: Özgür Ulubey, Faculty of Education, Muğla Sttkı Koçman University, Muğla, Turkey.
}

Received: February 1, 2018

doi:10.11114/jets.v6i3.2968

\author{
Accepted: March 1, $2018 \quad$ Online Published: March 7, 2018 \\ URL: https://doi.org/10.11114/jets.v6i3.2968
}

\begin{abstract}
The aim of the current study was to synthesize the findings of experimental studies addressing the effect of the creative drama method on the skills of students. Research data were derived from ProQuest Citations, Web of Science, Google Academic, National Thesis Center, EBSCO, ERIC, Taylor \& Francis Online, and ScienceDirect databases using keywords such as drama, and skill. A total of 63 research studies including twenty articles, thirty-four master's and nine doctoral theses, which met the inclusion criteria of meta-analysis, formed the data source of the current study. The collected data were analyzed by using the Comprehensive Meta Analysis program. To address the heterogeneity of the studies, the random effects model were employed to calculate the effect size. The results of the research showed that creative drama method positively affected the skills of students. In experimental studies, the differences in the effect created by the creative drama on students' skills were examined in terms of moderator variables. While the effect size of creative drama on students' skills was found to be significantly varying depending on the moderator variables including the duration of experimental application, the level of schooling and the publication type, it was found that the effect size was not significantly varying depending on the moderator variables of practitioner and types of skills.
\end{abstract}

Keywords: creative drama, skills, meta-analysis

\section{Introduction}

Creative drama "is the animation of a purpose or a thought on the basis of the experiences of a group or group members by making use of techniques such as improvisation and role-playing" (Adiguzel, 2017, p. 56). While Heathcote (1984) defines creative drama as a means of increasing the life experiences of an individual, O'Neill and Lambert (1991) define it as a learning method improving imagination and helping to learn the connections between situations easily. Creative drama is seen as a form of art in which actions such as role-playing, enacting a thing or a person are performed to reflect human situations (Taylor, 2000). Creative drama is the conversion of an imaginary thought into action and the recreation of perceptions related to the world and humans by students and teachers through role-playing (Courtney, 1989; McNaughton, 2004).

Since 1950s, creative drama has been used as a method as it can raise children's awareness of the periods in which they live. Besides England, it was utilized as a method in such countries as Holland, Canada, Australia, Scandinavian countries, and, the USA. Over time, creative drama began to be taught as a course in curricula in order to ensure the personality and aesthetic development of students and sometimes it was used as a means of art education (Adiguzel, 2017; Ustundag, 1996). In this respect, creative drama; as a teaching method, a means of art education and a discipline, has an important role in developing cognitive behaviors, emotional and psychomotor traits (Ustundag, 2010). In the current study, it is aimed at investigating the effectiveness of creative drama as a teaching method by utilizing meta-analysis.

The creative drama method allows learners to improvise by sharing roles with their group members (Adiguzel, 2017) and learn by doing and experiencing (Chalmer, 2007). These improvisations carry traces of life (Baldwin \& Fleming, 2003). Studies show that the creative drama method enables students to participate effectively in the learning process and increases their desire for learning, self-confidence and courage (Ulubey \& Gozutok, 2015). The creative drama method that improves the different characteristics of students makes a positive contribution to their cognitive and affective development. Some research focusing on the effectiveness of the creative drama method has revealed that this method enhances students' academic achievement (Biyikli \& Yagci, 2015; Dikmenli Vardar, 2015; Fleming, Merrell \& Tymms, 2004; Francis, 2007; Ulubey \& Gozutok, 2015; Walker, Tabone \& Weltsek, 2011) and improves their attitudes 
towards some courses (Ceylan, 2014; Debreli, 2011; Hendrix, Eick \& Shannon, 2012; Ormanci \& Ozcan, 2014).

In addition to its effect on academic achievement and course attitude, the effect of the creative drama method on the development of skills has been widely investigated. According to the Turkish Language Association (2018), skill is defined as "the ability of a person to achieve a task and to conclude an action appropriately depending on his / her predisposition and training". Skills are addressed by many names in the literature and in the current study, these were combined and named as social, basic language and higher thinking skills. These skills were determined to be moderator variables.

The first moderator variable whose effect is investigated in the current study is social skills. Social skills are learned behaviors that include verbal and non-verbal behaviors, enable individuals to initiate positive behaviors, maintain these behaviors and respond appropriately to social contexts they are in (Gulay \& Akman, 2009; Yigit \& Yilmaz, 2011). Social skills, which play an important role in individuals' adapting to the environments in which they live, are important in the accomplishment of social goals and in the establishment of interpersonal relationships (Sorias, 1986). Individuals need to establish proper relationships with others in order to maintain a healthy life in the society. Social skills are at the core of healthy relationships that can be established among individuals (Samanci \& Ucan, 2017). Social skills enable individuals to understand their own and others' feelings, thoughts and behaviors (Cubukcu \& Gultekin, 2006).

There are different classifications of social skills in the literature. On the one hand, Eisler and Fredericksen (1980) classified social skills as verbal, non-verbal and motor skills. On the other hand, Elliot and Busse (1991) as cooperation, proposition making, responsibility taking, empathy and self-control skills. Addition to these, Rinn and Markle's (1979) classification is comprised of environment broadening, self-expression, communication and assertiveness skills. Lastly, Caldarella and Merrell (1997) classified social skills as self-control, peer relationship, adaptation, assertiveness and academic skills. When the classifications of social skills are examined, it becomes clear that a common classification seems to be impossible due to their nature.

Social skills are very important in the child's social development. In addition, recent studies have indicated that social skills can be effective in terms of academic and business achievement as well as social development in the later life of the individual (Lynch \& Simpson, 2010). Therefore, the methods used in the development of social skills are important. It has been stated that techniques and methods such as being a model, role-playing, demonstration, cooperative learning, direct learning, cognitive learning, social learning and peer-assisted learning, drama, information-giving, discussion, feedback-giving and home activities can be used for social skill development (Eldeniz Cetin, 2005). In addition, for the success of social skills training depends on equal participation of group members, healthy communication between the group members and rapport. One possible way of achieving all these is the creative drama method. When the experimental research on the development of social skills is reviewed, it is seen that the creative drama method improved the social skills of students (Mantas, 2014; Onemli, Totan \& Abbasov, 2015; Yilmaz, 2013).

Another moderator variable investigated in the current study is language skills. Language skills need to be developed so that effective communication can be achieved by using the language correctly. There are four basic skills in language teaching: reading, writing, speaking and listening. It is aimed to develop these four basic skills in language teaching. These skills are also named as receptive and productive skills. Productive skills include writing and speaking skills and receptive skills include reading and listening skills (Kavcar, Oguzkan \& Sever 1999; Sever, 2011).

It is necessary to conduct experimental studies and to report their results to determine which methods should be used for the development of the basic language skills (Sever, 2011). Various activities are being carried out for the development of basic language skills, starting with the pre-school period. These activities include play, story completion, story building, dramatization, pantomime, role playing, improvisation and creative drama. Language skills can be improved by using one or more of these methods (Onder, 2001). One of the commonly used methods for the better teaching of basic language skills is the creative drama method. As a result of the literature review, it was concluded that the creative drama method improved students' basic language skills such as speaking (Aykac \& Cetinkaya, 2013; Kardas \& Koc, 2017; Maden, 2010; Su Bergil, 2010; Ulas, 2008), listening (Cakir, 2013; Maden, 2010), reading (Erden, 2016) and writing (Erkan \& Aykac, 2014; Kaya Guler, 2008).

Another moderator variable investigated in the current study is higher thinking skills. Higher thinking skills emerged on the basis of Bloom's taxonomy (Brown, 2004). Definition of higher thinking skills is difficult; yet, they are easy to recognize when observed. The development of higher thinking skills has always been an objective targeted by qualified educational institutions. Higher thinking skills are the key to successful learning at every level of schooling (Alexander et al., 2011). However, the basic difficulty involved here is to find the means of teaching higher thinking skills in educational institutions responsible for the education of general public.

Higher thinking skills are defined as the process of integration, reasoning, problem solving and comprehension (Fisher, 1990). Higher thinking skills include cognitive activities such as planning, tackling uncertain situations, reaching judgments, being open-minded, problem solving, critical and flexible thinking, decision-making, knowledge generation 
and creative thinking (Cakir, 2013). In the current research, higher thinking skills such as critical thinking, problem solving, reflective thinking, creative thinking and decision-making were addressed within the context of the creative drama method. It was determined that the creative drama method developed higher thinking skills such as critical thinking (Bapoglu, Acikgoz, Kapisiz \& Yilmaz, 2011; Yagmur, 2010), problem solving (Senol Ozyigit, 2011; Tanriseven, 2000), reflective thinking, creative thinking and decision-making (Cakmakci, 2009).

The data collected in the current study were investigated in relation to the moderator variables of the duration of experimental application, practitioner, and level of schooling and publication type as well as types of skills. The duration of experimental application is important. It is of particular importance for the development of skills. With increasing duration of experimental application, the effectiveness of the experiment is expected to increase because skills are not prone to change in shorter time periods. In addition to this, applications are suggested to be conducted by the same individual(s) in order to ensure control in experimental and control groups in experimental studies. Therefore, the practitioner was also determined to be a moderator variable. The data of the study are derived from articles and theses. The time allocated for these studies and the difficulty levels of the studies can vary. Therefore, the publication type was set to be a moderator variable. The studies examined within the context of the current study cover a wide range stretching from pre-school period to higher education. The skill development of students may vary between different developmental periods, different age groups and depending on the purpose. Thus, a total of five moderator variables were determined in the current study. In the meta-analysis study conducted by Toraman and Ulubey (2016) to determine the effect of the creative drama method on attitudes, similar moderator variables were determined and significant differences were found to be stemming from these moderator variables. The current study also addresses these moderator variables.

When the studies focusing on the effect of the creative drama method on skills are holistically evaluated, it can be argued that the creative drama method enhances students' skills such as communication, empathy, imagination, creativity, critical thinking, cooperation, social awareness and emotion recognition (Akar Vural \& Somers, 2011; Aykac \& Adiguzel, 2011; Freeman, Sullivan \& Fulton, 2010; Kao \& O' Neill, 1998; Onder, 2001; Ustundag, 2014). While in many of the studies a statistically significant difference in favor of the experimental group was found (Aslan, 2008; Comertpay, 2006; Koc, 2009; Kocayoruk, 2000; Onemli et al., 2015; Tanriseven, 2000), no difference was found between the control group and the experimental group in some others (Eti, 2010; Gomez, 2010; Kaf, 2000; Kortan, 2010; Maden, 2010; Onur, 2016; Yilmaz, 2013). Therefore, it is important to bring related studies together to summarize their results, to synthesize these studies and to determine the effect of the creative drama method on students' different skills in a holistic manner. Such a work can only be performed by means of meta-analysis.

Meta-analysis "is the grouping of similar studies conducted about a certain subject or field in line with specific criteria and the analysis of quantitative findings of these studies combined" (Hunter, Jackson \& Schmidt, 1991 cited in Erkus, 2013, p. 109; Dincer, 2014, p. 4). Meta-analysis allows the interpretation and detailed synthesis of the results of similar and different studies; thus, gives a direction to new researchers and research (Schulze, 2007).

In the literature, there are meta-analysis studies exploring the effect of the creative drama method on students' academic achievement (Akdemir \& Karakus, 2016; Aydin, Kasarci \& Yurt, 2012; Batdi \& Batdi, 2015; Bicer, 2017; Canturk Gunhan, 2016; Lee, Patall, Cawthon, \& Steingut, 2015; Ulubey \& Toraman, 2015) and attitudes towards different courses (Toraman \& Ulubey, 2016). In these studies, it was concluded that the creative drama method is effective in these respects. There is also a meta-analysis study looking into the effect of the creative drama method on self-esteem (Conard \& Asher, 2000). Yet, it was determined that no meta-analysis study had been conducted to investigate the effect of the creative drama method on students' skills. In this regard, the current study aimed to bring the experimental studies exploring the effect of the creative drama method on students' skills and to synthesize their findings. In this connection, the following hypotheses were tested.

H1: There is a significant difference between the skills of the students taught through the creative drama method and those of the students taught through other methods and techniques.

H2: Different experimental application times are a significant moderator variable on the effect size.

H3: Different practitioners are a significant moderator variable on the effect size.

H4: Different levels of schooling are a significant moderator variable on the effect size.

H5: Different publication types are a significant moderator on the effect size.

H6: Different skills are a significant moderator on the effect size.

\section{Method}

In the current study, a meta-analysis of the experimental studies conducted to develop students' skills by means of the creative drama method was performed to reveal the effect of the creative drama method on students' skills. 


\subsection{Data Collection}

Key words such as creative drama, drama, creative drama method, skill, problem solving, critical thinking, social skills and communication skills were used to reach research data. These key words were searched in ProQuest Citations, Google Academic, Tukish Higher Education Institution National Thesis Center, Taylor \& Francis, EBSCO, ScienceDirect and ERIC databases. In this way, a total of 63 studies including twenty articles, thirty four master's and nine doctoral theses which met the criteria of meta-analysis were reached. These studies had been carried out between 1995 and 2017.

Table 1. Descriptive statistics related to the experimental studies investigating the effect of the creative drama method on students' skills

\begin{tabular}{lll}
\hline Variables & Levels & $\mathrm{n}$ \\
\hline Duration of Experimental Application & $1-10$ hours & 8 \\
& $11-20$ hours & 20 \\
& $21-30$ hours & 18 \\
& $31-40$ hours & 7 \\
& 41 hours and more & 4 \\
Practitioner & Not stated & 6 \\
& Total & 63 \\
& Researcher & 41 \\
Level of Schooling & Teacher & 12 \\
& Total & 63 \\
& Pre-school & 9 \\
& Elementary school & 15 \\
& Secondary school & 18 \\
& High school & 11 \\
Publication Type & University & 6 \\
& Not stated & 4 \\
& Total & 63 \\
Skills & Article & 20 \\
& Master's Thesis & 34 \\
& Doctoral Thesis & 9 \\
& Total & 63 \\
& Social Skills & 22 \\
& Basic Language Skills & 27 \\
& Higher Thinking Skills & 14 \\
& Total & 63 \\
\hline
\end{tabular}

As shown in Table 1, there are different durations of experimental applications such as 1-10 ( $\mathrm{f}=8), 11-20(\mathrm{f}=20), 21-30$ $(\mathrm{f}=18), 31-40(\mathrm{f}=7)$ and 41 hours and more $(\mathrm{f}=4)$. The experimental application duration is not stated in six studies. A great majority of the experimental applications were conducted by the researcher $(\mathrm{f}=41)$ and relatively fewer of them were conducted by the teacher $(\mathrm{f}=12)$. Some studies were conducted on pre-school children $(\mathrm{f}=9)$, some on elementary school students $(\mathrm{f}=15)$, some on secondary school students $(\mathrm{f}=18)$, some on high school students $(\mathrm{f}=11)$ and relatively fewer on university students ( $\mathrm{f}=4)$. The level of schooling is not stated in four studies. Most of the studies are master's theses ( $\mathrm{f}=34)$, followed by articles $(\mathrm{f}=20)$ and doctoral theses $(\mathrm{f}=9)$ and they investigated the effect on basic language skills $(\mathrm{f}=27)$, social skills $(\mathrm{f}=22)$ and higher thinking skills $(\mathrm{f}=14)$.

\subsection{Criteria for Inclusion in the Meta-analysis}

The experimental studies conducted to develop skills by means of the creative drama method were included in the current study according to some criteria determined by the researcher. In the chosen studies, the students in the experimental groups were instructed by means of the creative drama method and the students in the control groups were instructed by means of other methods and techniques. Posttest measurements, arithmetic means and standard deviation values were given for both the experimental and control groups. The number of the participants in the studies was clearly stated. The studies were articles and theses produced as a result of scientific research. The participants' level of schooling, the duration of the experimental application, who the practitioner was, publication type and the date of publication were stated in the studies. The studies were conducted in the formal education institutions.

\subsection{Data Analysis}

As the first step to analyzing the data, a coding key was constructed to determine the studies to be included in the analysis. The key had some headings such as the study number, the author or authors, date of publication, place where the study had been conducted, sampling sizes of the experimental and control groups, arithmetic means and standard deviations, the duration of the experimental application, the practitioner of the study, the level of schooling, skills and common skills. The data obtained from the studies meeting the designated criteria were entered into CMA program and then analyzed. 
In meta-analysis studies, fixed and random effects models can be used to calculate the effect size (Borenstein, Hedges, Higgins \& Rothstein, 2009). The fixed effects model is built on the assumption that all the studies involved in a meta-analysis have only one real effect size; on the other hand, the random effects model is built on the assumption that variables such as age, education level and class size can change the effect size (Alpaslan, Yalvac \& Willson, 2017; Ustun \& Eryilmaz, 2014). By using the Q statistics in the meta-analysis, whether all the studies share the general effect is tested and thus, the researcher can decide which effect model to use. As a result of the analysis, the significance value was found to be below the (p) critical value, indicating that there is heterogeneity among the studies (Card, 2012; Hedges \& Olkin, 1985, Pigott, 2012). I2 statistics also give information about the ratio of heterogeneity to researchers. In the current study; as the $\mathrm{Q}$ statistics showed that the studies are heterogeneous, the random effects technique was used to calculate the effect size.

In meta-analysis studies, publication bias is determined by means of the funnel plot. A symmetrical funnel plot indicates the absence of publication bias. The studies investigated in the current study are gathered in the upper and internal parts of the funnel plot, indicating that their contributions to the effect size are great. Cooper, Hedges and Valentin (2009) found that an asymmetry occurs in the graph in case of publication bias. They stated that the studies making limited contributions to the effect size are placed at the bottom edges of the funnel. In the current research, the funnel plot was used to determine how much the studies contributed to the effect size and how symmetric they were.

Moderator analysis is a method of analysis that allows to determine the direction of the differences in the sub-groups determined within the scope of research and the differences between the mean effect sizes of variables (moderators) (Littel, Corcoran \& Pillai, 2008). The statistical significance of moderator variables is determined through Q statistics (Hedges \& Olkin, 1985). This technique is executed over two different $\mathrm{Q}_{\mathrm{s}} ; \mathrm{Q}_{\text {between }}\left(\mathrm{Q}_{\mathrm{B}}\right)$ and $\mathrm{Q}_{\text {within }}\left(\mathrm{Q}_{\mathrm{w}}\right)$. While $\mathrm{Q}_{\mathrm{w}}$ tests the homogeneity of the moderator variable in itself, $\mathrm{Q}_{\mathrm{b}}$ tests between-groups homogeneity (Card, 2012; Hedges \& Olkin, 1985). In the current study, in addition to the effect of the creative drama method on students' skills, it was also investigated whether this effect varies significantly depending on the moderator variables of duration of experimental application, practitioner, level of schooling, publication type, and skills. Their statistical significance was examined by using $\mathrm{Q}_{\mathrm{b}}$ values.

Cohen's (1988) classification was used to determine the magnitude of effect size in the current study. Effect size can vary between 0 and 1 . Yet, some effect sizes can be found bigger than 1. In Cohen's classification, a value in the range $0-.20$ is accepted to be indicating weak effect, $.21-.50$ small effect, $.51-.80$ medium effect, and .80 and higher values indicate large effect.

\section{Results}

\subsection{Findings Related to the Effect of the Creative Drama Method on Skill Development}

Prior to the calculation of the effect size in the current study, the studies were determined to be heterogeneous $(\mathrm{Q}(62)=832.574, \mathrm{p}<.05)$. The result of $\mathrm{Q}$ statistics was found to be significant, indicating that the studies are different from each other. The studies were found to be heterogeneous at the level of $92.56 \%$ (I2 $=92.55 \%$ ). According to Cooper et al. (2009), an I2 value higher than $75 \%$ shows that heterogeneity is high. This required the calculation of the effect size by means of the random effects model.

In Figure 1, the loadings of the studies included in the study and their effect sizes are shown one by one. In high majority of the studies, a significant difference in favor of the experimental group was found. This shows that in majority of the studies the creative drama method positively contributed to the development of students' skills. 


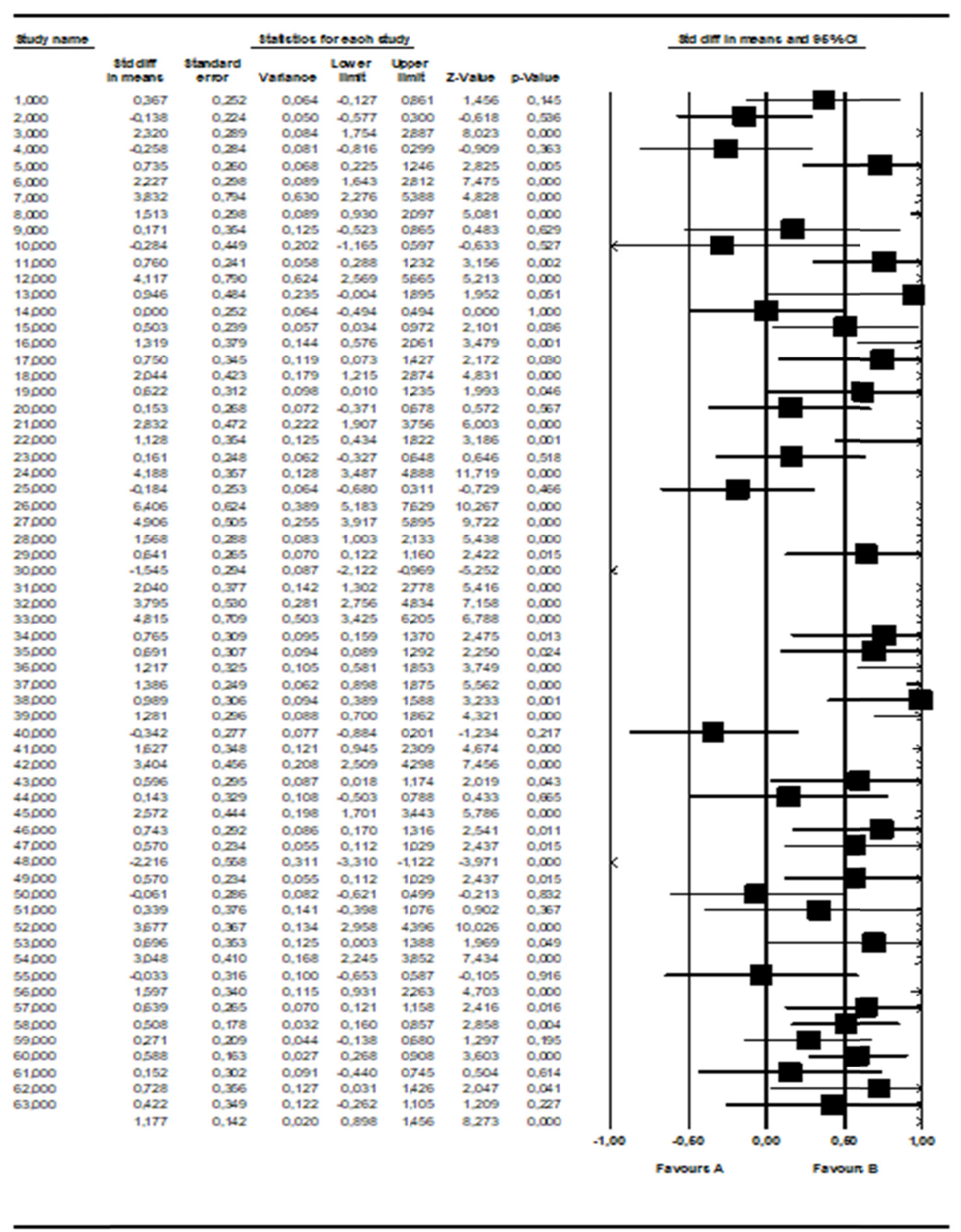

Figure 1. Forest plot related to the effect of the creative drama method on skill development

Table 2. Meta-analysis effect size findings obtained through the random effects model

\begin{tabular}{lllllll}
\hline $\mathrm{ES}$ & $\mathrm{Z}$ & $\mathrm{Q}$ & $\mathrm{I}^{2}$ & $\mathrm{~S}_{\text {hata }}$ & $\mathrm{ES}_{\min }$ & $\mathrm{ES}_{\max }$ \\
\hline $1.177^{* * *}$ & 8.273 & $832.574 * * *$ & 92.553 & .142 & .898 & 1.456 \\
\hline
\end{tabular}

As shown in Table 2, the mean effect size was found to be statistically significant in the $95 \%$ confidence interval $(\mathrm{Z}=8.273, \mathrm{p}<.05)$. The mean effect size in the current study was found to be 1.177 and positive. This shows that the effect of the application is in favor of the experimental group. According to Cohen's (1988) classification, this effect size is large; according to Thalheimer and Cook's (2002) classification, it coincides with a very large effect size. That is, the lessons taught by using the creative drama method made positive contributions to the development of students' skills. This finding shows that the first hypothesis is supported. 


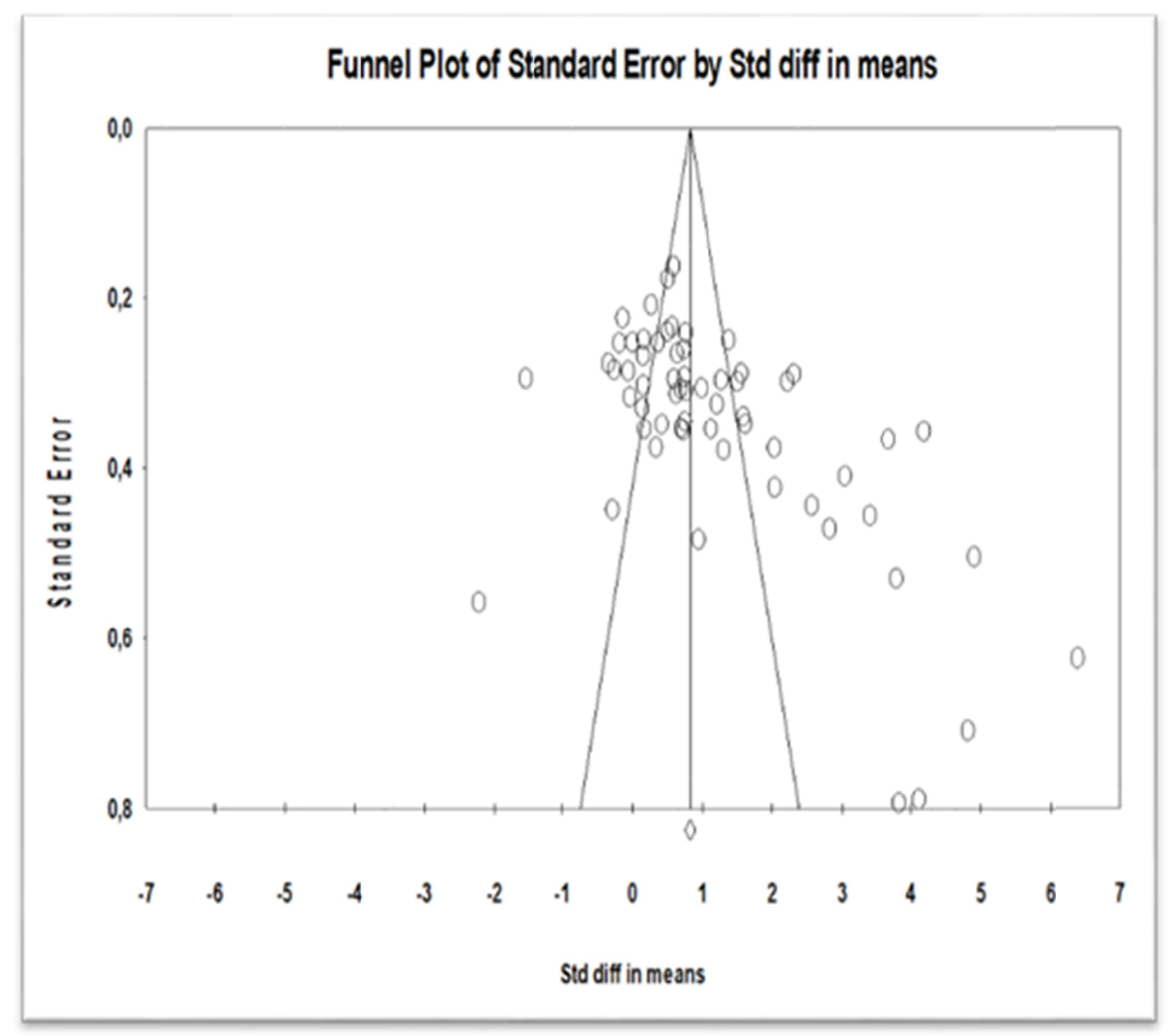

Figure 2. Publication bias funnel plot

As can be seen in Figure 2, majority of the studies included in the meta-analysis are gathered in the upper and internal parts of the funnel plot. This shows that the contribution of the studies included in the analysis to the meta-analysis is large. In addition to this, it was determined that both sides of the funnel plot are not symmetric. On the right part of the plot, there are some studies destroying the symmetry. Destruction of the symmetry indicates the presence of publication bias. In order to make the plot symmetric, a correction was made by using the "crop-paste" shifting method, and in this way, eight studies were shifted to the other side. As a result, the effect size value was found to be 1.455 . This value coincides with a large effect size according to Cohen's (1988) classification.

\subsection{The Effect of the Creative Drama Method on Skill Development (Moderator Variables)}

The studies investigating the effect of the creative drama method on skill development were analyzed in relation to the moderator variables of the duration of experimental application, practitioner of the research, publication type, level of schooling and skills. 
Table 3. The effect of the creative drama method on skill development in relation to moderator variables

\begin{tabular}{|c|c|c|c|c|c|c|c|c|c|}
\hline \multirow[t]{2}{*}{ Moderator Variable } & \multirow{2}{*}{$\begin{array}{l}\text { Level of moderator } \\
\text { variable }\end{array}$} & \multirow[t]{2}{*}{$\mathrm{N}$} & \multirow[t]{2}{*}{ ES } & \multirow{2}{*}{$\mathrm{S}_{\text {hata }}$} & \multirow[t]{2}{*}{ Z } & \multicolumn{2}{|c|}{$\begin{array}{l}\text { Effect size in } \\
\text { confidence interval }\end{array}$} & \multirow{2}{*}{$\begin{array}{l}Q_{\text {between }} \\
\left(Q_{b}\right)\end{array}$} & \multirow[t]{2}{*}{$\mathrm{df}$} \\
\hline & & & & & & $\mathrm{ES}_{\text {bottom }}$ & $\mathrm{ES}_{\text {top }}$ & & \\
\hline \multirow{6}{*}{$\begin{array}{l}\text { Duration of experimental } \\
\text { application }\end{array}$} & 1-10 hours & 8 & .525 & .164 & $3.198 * * *$ & .203 & .847 & \multirow{6}{*}{$13.554^{*}$} & \multirow{6}{*}{5} \\
\hline & 11-20 hours & 20 & 1.071 & .248 & $4.309 * * *$ & .584 & .558 & & \\
\hline & 21-30 hours & 18 & 1.769 & .363 & $4.874 * * *$ & 1.058 & 2.481 & & \\
\hline & $31-40$ hours & 7 & 1.514 & .438 & $3.456 * * *$ & .655 & 2.373 & & \\
\hline & 41 hours and more & 4 & 1.173 & .297 & 3.567 & .793 & 2.239 & & \\
\hline & Not Stated & 6 & .838 & .177 & $4.741 * * *$ & .492 & 1.185 & & \\
\hline \multirow[t]{2}{*}{ Practitioner } & Researcher & 51 & 1.154 & .163 & $7.077 * *$ & .835 & 1.474 & \multirow{2}{*}{.130} & \multirow{2}{*}{1} \\
\hline & Teacher & 12 & 1.273 & .287 & $4.440 * * *$ & .711 & 1.836 & & \\
\hline \multirow[t]{6}{*}{ Level of schooling } & Pre-school & 9 & 2.596 & .491 & $5.291 * * *$ & 1.430 & 3.443 & & \multirow{6}{*}{5} \\
\hline & Elementary school & 15 & 1.057 & .226 & $4.684 * * *$ & .615 & 1.499 & \multirow{5}{*}{$28.895 * * *$} & \\
\hline & Secondary school & 18 & 1.357 & .288 & $4.715 * * *$ & .793 & 1.921 & & \\
\hline & High school & 11 & .122 & .291 & .417 & -.449 & .692 & & \\
\hline & University & 6 & 1.388 & .412 & $3.366 * * *$ & .580 & 2.196 & & \\
\hline & Not stated & 4 & .514 & .161 & $3.182 * * *$ & .197 & .830 & & \\
\hline \multirow[t]{3}{*}{ Publication type } & Article & 20 & .830 & .186 & $4.462 * * *$ & .465 & 1.195 & \multirow{3}{*}{$6.418^{*}$} & \multirow{3}{*}{2} \\
\hline & Master's thesis & 34 & 1.040 & .186 & $5.605 * * *$ & .676 & 1.404 & & \\
\hline & Doctoral thesis & 9 & 2.489 & .633 & $3.933 * * *$ & 1.249 & 3.730 & & \\
\hline \multirow[t]{3}{*}{ Skills } & Social skills & 22 & .900 & .178 & $5.071 * *$ & .552 & 1.248 & \multirow{3}{*}{3.597} & \multirow{3}{*}{2} \\
\hline & $\begin{array}{l}\text { Basic language } \\
\text { skills }\end{array}$ & 27 & 1.481 & .253 & $5.860 * *$ & .986 & 1.977 & & \\
\hline & $\begin{array}{l}\text { Higher } \\
\text { skills }\end{array}$ & 14 & 1.002 & .340 & $2.948 * *$ & .336 & 1.667 & & \\
\hline
\end{tabular}

$$
* \mathrm{p}<.05, * * \mathrm{p}<.01, * * * \mathrm{p}<.001
$$

The first moderator variable in Table 3 is the duration of experimental application. It was found that the duration of experimental application in the studies investigated in the study varies between 1-10 and 41 and more hours and the duration of experimental application was determined to be the moderator variable. As a result of the analysis, it was found that the effect size significantly varies depending on the duration of experimental application $\left(\mathrm{Q}_{B}=13.554, \mathrm{p}<.05\right)$. The effect size in the experimental application of 21-30 hours $(\mathrm{ES}=1.769)$ and 31-40 hours $(\mathrm{ES}=1.514)$ is large according to the Cohen's (1988) classification. The effect size in the experimental application of 1-10 hours is medium $(\mathrm{ES}=.525)$. This shows that the effect size of the longer experimental applications is larger than that of the shorter experimental applications.

It was also found that the effect size does not vary significantly depending on the practitioner moderator variable $\left(\mathrm{Q}_{\mathrm{B}}=.130 ; \mathrm{p}>.05\right)$. The effect sizes found in the studies conducted by both teachers $(\mathrm{ES}=1.273)$ and researchers ( $\mathrm{ES}=1.154)$ are large according to the Cohen's (1988) classification. This finding shows that the effect size is similar regardless of the practitioner.

The moderator variable of level of schooling includes the levels of pre-school, elementary school, secondary school, high school and university. It was found that the effect size varies significantly depending on the moderator variable of school level $\left(\mathrm{Q}_{\mathrm{B}}=28.895, \mathrm{p}<.01\right)$. The highest effect size was found in the pre-school level and the lowest effect size was found in the high school level $(\mathrm{ES}=.122)$.

The publication type was found to be a moderator variable causing a significant difference in the effect size $\left(\mathrm{Q}_{\mathrm{B}}=6.418, \mathrm{p}<.05\right)$. The effect sizes of the master's theses $(\mathrm{ES}=1.040)$ and doctoral theses $(\mathrm{ES}=2.489)$ were found to be higher than that of the articles (ES=.830). According to the Cohen's (1988) effect size classification, a large effect was found in all the groups.

The skills on which the effect of the creative drama method was investigated have been classified as social skills, basic language skills and higher thinking skills. These were determined to be a moderator variable under these headings. The effect size was found to be not varying significantly depending on this moderator variable $\left(\mathrm{Q}_{\mathrm{B}}=3.597, \mathrm{p}>.05\right)$. The social $(\mathrm{ES}=.900)$, basic language $(\mathrm{ES}=1.481)$ and higher thinking $(\mathrm{ES}=1.002)$ skills were found to have large and similar effect sizes according to the Cohen's (1988) classification.

When the findings of the current study are subjected to a general evaluation, it is seen that while the effect size varies significantly depending on the moderator variables of the duration of experimental application, level of schooling, publication type, it does not vary significantly depending on the moderator variables of practitioner and skills.

\section{Discussion}

In the current study, in which the effect of the creative drama method on students' skills was investigated, a meta-analysis was conducted with 63 studies meeting the designated criteria. It was determined that the studies included 
in the meta-analysis have publication bias and are heterogeneous. Due to this heterogeneity, the effect size was calculated by means of the random effects model and a significant effect size was found (ES=1.177). This effect size is in favor of the experimental groups and according to Cohen's (1998) classification, it is large. This shows that the creative drama method makes a positive contribution to the development of students' skills. In the literature, there is no study investigating the effect of the creative drama method on the development of students' skills. On the other hand, there are studies exploring the effect of the creative drama method on students' attitudes towards courses (Toraman \& Ulubey, 2016) and academic achievement (Akdemir \& Karakus, 2016; Aydin et al., 2012; Batdi \& Batdi, 2015; Bicer, 2017; Lee \& et al., (2015); Ulubey \& Toraman, 2015). In all of these studies, it is seen that the creative drama method positively affected students' attitudes towards courses and academic achievement. It was concluded that the creative drama method positively affected students' skills as well as their course attitudes and academic achievement. When these three findings are evaluated together, it can be argued that the creative drama method enhances students' cognitive, affective and psychomotor characteristics. In the curricula of elementary and secondary education there are cognitive, affective and psychomotor objectives. Though it is stated that not all the problems can be solved by using the creative drama method, it seems to be advisable to make more use of this method, which can develop cognitive, affective and psychomotor characteristics of students.

In the current study, the duration of experimental application, implementer, level of schooling, publication type and skills were set to be moderator variables and whether significant differences occurred in the effect sizes depending on these variables was investigated. The duration of experimental application variable was found to be leading to a significant difference $\left(\mathrm{Q}_{\mathrm{B}}=13.554, \mathrm{p}<.05\right)$. With increasing duration of experimental application, the effect of the application is expected to increase. The effect size found in the studies whose experimental application lasted for 1-10 hours (ES=.525) is smaller than the effect size found in the studies whose experimental application lasted for 21-30 (ES=1.769) and 31-40 hours. In a similar manner, in the meta-analysis study conducted by Toraman and Ulubey (2016) to investigate the effect of the creative drama method on the course attitude it was found that the application time designated as the moderator variable has a significant impact on effect size. On the other hand, in the meta-analysis study conducted by Canturk Gunhan (2016) to investigate the effect of the creative drama method on math achievement, it was found that effect size did not vary significantly by application time. The reason for this different finding may be because the application times determined for the groups were large. In light of the research findings, it can be argued that longer application times are better than shorter application times in terms of increasing the effect size in experimental studies.

One of the variables that need to be kept under control in experimental research is the implementer. It is questionable whether the teacher or the researcher should be the implementer. In this regard, it is thought that the researcher knows the subject of interest better but can act biased; on the other hand, the teacher might not act biased but lack enough mastery of the subject of interest. The results obtained from the groups of these two different implementers can be different. In order to determine whether the significant differences found in the studies included in the current research stemmed from the experimental application or the implementer, the practitioner moderator variable was employed. Yet, the practitioner moderator variable was found to be not leading to a significant difference $\left(\mathrm{Q}_{\mathrm{B}}=.130 ; \mathrm{p}>.05\right)$. This finding indicates that the effect sizes of the studies conducted by researchers $(\mathrm{ES}=1.154)$ and teachers $(\mathrm{ES}=1.273)$ are close to each other. A similar finding is obtained in the study by Toraman and Ulubey (2016). The practitioner needs to have had drama training to implement the creative drama method. The finding of the current study that the effect sizes found in the groups of the both implementers are close to each other indicates that the teachers and researchers may have undergone drama training. Therefore, a significant difference may not have been found between two groups. Thus, it can be argued that there is no bias stemming from the practitioner in the studies focusing on the effect of the creative drama method on skill development.

As students from different levels of schooling are at different stages of development and in different age groups, some differences may be observed in their skill development. Therefore, the level of schooling was appointed to be a moderator variable in the current study. It was found that this moderator led to a significant difference in the effect size $\left(\mathrm{Q}_{B}=28.895\right.$, $\mathrm{p}<.01)$. The effect sizes of the groups in pre-school $(\mathrm{ES}=2.596)$, secondary school $(\mathrm{ES}=1.357)$, elementary school $(\mathrm{ES}=1.057)$ and university $(\mathrm{ES}=1.388)$ were found to be higher than that of the groups in high school $(\mathrm{ES}=.122)$. In the study by Toraman and Ulubey (2016), the level of schooling was also appointed as a moderator variable and the effect of this moderator was found to be statistically significant. In the study in which Akdemir and Karakus (2016) investigated the effect of the creative drama on the achievement, it was found that the level of schooling led to significant differences in the effect size. In other meta-analysis studies looking at the effect of the creative drama method, it has been revealed that the level of schooling is not a variable causing significant differences (Batdi \& Batdi, 2015; Canturk Gunhan, 2016; Ulubey \& Toraman, 2005). Yet, in general the development observed in the experimental groups was found to be higher. Particularly the effect of the creative drama method used in pre-school level was determined to be higher than the other levels. Adiguzel (2017) remarked that play is effective in developing children's cognitive, psychomotor, affective and higher thinking skills. Drama is built on play. As children in the pre-school period are in the age of play and the drama is grounded 
on play and animation, the creative drama method may have been more effective on children.

In the current study, it was concluded that the publication type moderator variable led to a statistically significant difference in the effect size $\left(\mathrm{Q}_{\mathrm{B}}=6.418, \mathrm{p}<.05\right)$. The effect sizes found in the doctoral theses $(\mathrm{ES}=2.489)$ and the master's theses $(\mathrm{ES}=1.040)$ studies are higher than the article studies $(\mathrm{ES}=.830)$. This finding concurs with the finding reported by Canturk Gunhan (2016). Articles, master's and doctoral theses are works requiring long time and great effort. The effect sizes obtained from these works comply with the expectations. Detection of significant effect size in meticulous studies requiring long time to prepare is a positive finding.

The skills investigated in the studies included in the current meta-analysis are grouped as social skills, basic language skills and higher thinking skills and taken as a moderator variable. It was concluded that the effect size does not vary significantly depending on the skill type $\left(\mathrm{Q}_{\mathrm{B}}=3.597, \mathrm{p}>.05\right)$. This finding shows that the effect sizes of social skills $(\mathrm{ES}=.900)$, basic language skills $(\mathrm{ES}=1.481)$ and higher thinking skills $(\mathrm{ES}=1.002)$ are close to each other. However, these three groups of skills were found to have greater effect sizes in favor of the experimental groups. Lee \& et al., (2015) also found in their meta-analysis study that the creative drama method is effective in developing creative, critical thinking, communication and social skills. In light of these findings, it can be argued that the creative drama method is effective in developing cognitive, language and social skills.

There are many studies investigating the effect of the creative drama method on skills. Yet, there is no meta-analysis study combining all these studies and determining the effect sizes. The current study was conducted to determine the effect of the creative drama method on skills. It was concluded that the creative drama method is effective in developing skills. Qualitative research can be conducted to seek the reasons for this finding. In addition to this, a new meta-analysis can be conducted in the future studies to be published on the same subject.

In the current study, it was determined that the experimental application time moderator variable in the short studies is moderately effective in developing skills. This cannot be clearly associated with something. Future research may more elaborately focus on the experimental application time variable.

It was found that the number of studies investigating the effect of the creative drama method on skill development in pre-school, high school and university levels is limited. Thus, future research may focus on these levels of education more. This meta-analysis can be repeated if the unpublished papers and theses about the subject are discovered because not including studies whose data cannot be reached in meta-analysis research is known to increase the publication bias.

\section{References}

Adiguzel, O. (2017). Creative drama in education (Eğitimde yaratıcı drama) (10th ed.). Ankara: Pegem Academy. https://doi.org/10.14527/9786053644675

Akar, V. R., \& Somers, J. W. (2011). Drama in primary education for humanist primary education programs: theory and practice (Hümanist ilkögretim programları için ilkögretimde drama: Kuram ve uygulama.) Ankara: Pegem Academy.

Akdemir, H., \& Karakus, M. (2016). The effect of creative drama method on academic achievement: A meta-analysis study. International Journal of Active Learning, 1(2), 55-67.

Alexander, P. A., Dinsmore, D. L., Fox, E., Grossnickle, E. M., Loughlin, S. M., Maggioni, L., \& Winters, F. I. (2011). Higher-order thinking and knowledge: Domain-general and domain-specific trends and future directions. G. Schraw \& D. H. Robinson (Eds.), Assessment of higher order thinking skills. Current perspectives on cognition, learning and instruction (pp. 47-88). Charlotte, NC: IAP-Information Age Publishing, Inc.

Alpaslan, M, M., Yalvac, B., \& Willson, V. (2017). A meta analytical review of the relationship between personal epistemology and self-regulated learning. Turkish Journal of Education, 6(2), 48-67. https://doi.org/10.19128/turje.287472

Aslan, E. (2008). The effect of drama based social skill education on social intercourse and cooperation behaviours of 6 years old children (Unpublished master's thesis). Adnan Menderes University, Aydin, Turkey.

Aydin, M., Kasarci, I., \& Yurt, E. (2012, September). The success effect of the drama method: A meta-analysis study. Paper presented at the II. National Education Programs and Education Congress, Bolu, Turkey.

Aykac, M. (2011). The effect of creative drama activities on children's narration skills set up with child literature texts in Turkish teaching (Unpublished doctoral dissertation). Ankara University, Ankara, Turkey.

Aykac, M., \& Adiguzel, O. (2011). The effect of using creative drama as a method in social studies class on students'achievement. Kastamonu University Kastamonu Education Journal, 19(1), 297-314.

Aykac, M., \& Cetinkaya, G. (2013). The effect of creative drama activities on preservice Turkish language teachers' 
speaking skills. Electronic Turkish Studies, 8(9), 671-682.

Baldwin, P., \& Fleming, K. (2003). Teaching literacy through drama creative approaches. New York: Routledge.

Bapoglu, S. S., Acikgoz, F., Kapisiz, O., \& Yilmaz, O. (2011). Drama development method using the nursing students' critical thinking skills. Duzce University Health Sciences Institute Journal, 1(3), 17-21.

Batdi, V., \& Batdi, H. (2015). Effect of creative drama on academic achievement: A meta analytic and thematic analysis. Educational Sciences: Theory \& Practice, 15(6), 1459-1470. https://doi.org/10.12738/estp.2015.6.0156

Bicer, N. (2017). The influence of student-centered methods in Turkish language instruction on academic success: A Meta-analysis study. Universal Journal of Educational Research, 5(4), 687-697. https://doi.org/10.13189/ujer.2017.050419

Biyikli, C., \& Yagci, E. (2015). The effect of learning experiences designed according to 5e learning model on level of learning and attitude. Abant Izzet Baysal University Journal of Faculty of Education, 15(1), 128-164.

Borenstein, M., Hedges, L. V., Higgins, J. P. T., \& Rothstein, H. R. (2009). Introduction to meta analysis. UK: John Wiley \& Sons. https://doi.org/10.1002/9780470743386

Brown, T. (2004). Higher order thinking skills. In J. L. Kincheloe \& K. W. Danny (Eds.). Critical Thinking and Learning: An Encyclopedia for parents and teachers (pp. 458-463). Westport, CT: Greenwood Publishing Group.

Cakir, N. (2013). The effect of university education on the development of higher order thinking skills (Unpublished doctoral dissertation). Hacettepe University, Ankara, Turkey.

Cakmakci, E. (2009). Examination of the effect of drama lessons on 4th grade students of primary school when bringing in the abilities of decision making (Unpublished master's thesis). Eskisehir Osmangazi University, Eskisehir, Turkey.

Caldarella, P., \& Merrell, K. (1997). Common dimensions of social skills of children and adolescents: A taxonomy of positive behaviors. School Psychology Review, 26, 264-278.

Canturk, G. B. (2016). The effect of drama based learning applied in turkey on success of mathematics: A meta-analysis study. International Online Journal of Educational Sciences, 8(2), 145-162. https://doi.org/10.15345/iojes.2016.02.013

Card, N. A. (2012). Applied meta analysis for social science research. USA: The Guilford.

Ceylan, H. (2014). The effect of using creative drama method in lecturing the 6th grade maths course 'equality and equation' to students' attitudes (Unpublished master's thesis). Gazi University, Ankara, Turkey.

Chalmer, D. (2007). Drama 3-5 a practical guide to teaching drama to children in the foundation stage. NewYork: Routledge.

Cohen, J. (1988). Statistical power analysis for the behavioral sciences (2nd ed.). New Jersey: Lawrence Erlbaum Associates.

Comertpay, B. (2006). The effect of drama on acquisition of children aged 5-6 (Unpublished master's thesis). Cukurova University, Adana, Turkey.

Conard, F., \& Asher, W. J. (2000). Self-concept and self-esteem through drama: A Meta analysis. Youth Theatre Journal, 14 (1), 78-84. https://doi.org/10.1080/08929092.2000.10012519

Cooper, H., Hedges, L. V., \& Valentine, J. C. (2009). The handbook of research synthesis and meta analysis (2nd ed.). New York: Sage.

Courtney, R. (1989). Culture and the creative drama teacher. Youth Theatre Journal, 3(4), 18-23.

Cubukcu, Z., \& Gultekin, M. (2006). Social skills that need to be gained to primary school students. Journal of Social Sciences of the Turkic World, 37, 155-174.

Debreli, E. (2011). The effect of creative drama based instruction on seventh grade students' achievement in ratio and proportion concepts and attitudes toward mathematics (Unpublished master's thesis). Middle East Technical University, Ankara, Turkey.

Dikmenli-Vardar, G. (2015). The effect of teaching the respiratory system by dramatization technique to the students' achievements in primary school (Unpublished master's thesis). Gazi University, Ankara, Turkey.

Dincer, S. (2014). Applied meta-analysis in educational sciences (Eğitim bilimlerinde uygulamalı meta analiz). Ankara: Pegem Academy. https://doi.org/10.14527/pegem.001 
Eisler, R. M., \& Frederiksen, L. W. (1980). Perfecting social skills: A guide to interpersonal behavior development. New York: Plenum Pres. https://doi.org/10.1007/978-1-4613-3186-5

Eldeniz, C. M. (2005). The study on the effectiveness of the social skill-teaching programme prepared according to the drama method for the students with mental retardation (Unpublished master's thesis). Abant Izzet Baysal University, Bolu, Turkey.

Elliott, S. N., \& Busse, R. T. (1991). Social skills assessment and intervention with children and adolescents. School Psychology International, 12, 63-83. https://doi.org/10.1177/0143034391121006

Erden, G. (2016). The effects of the techniques of drama and cooperative learning onreading-comprehension skills, retention and attitude of fifth grade students (Unpublished master's thesis). Abant Izzet Baysal University, Bolu, Turkey.

Erkan, G., \& Aykac, M. (2014). The effects of creative drama activities constructed with samed behrengi books on the writing skills and attitudes of students. The Journal of International Social Research, 7(31), 600-610.

Erkus, A. (2013). Scientific research process for behavioral sciences (4th ed.). Ankara: Seckin.

Eti, I. (2010). The effects of drama activities on social skills of 5-6 years old children who enrolled in preschool institute (Unpublished master's thesis). Cukurova University, Adana, Turkey.

Fisher, R. (1990). Teaching children to think. Oxford: Blackwell.

Fleming, M., Merrell, C., \& Tymms, P. (2004). The impact of drama on pupils' language, mathematics, and attitudes in two primary schools. Research in Drama Education, 9, 177-199. https://doi.org/10.1080/1356978042000255067

Francis, M. (2007). The impact of drama on pupils' learning in science. School Science Review, 89, 91-102.

Freeman, G. D., Sullivan, K., \& Fulton, C. R. (2010). Effects of creative drama on self-concept, social skills, and problem behavior. The Journal of Educational Research, 96(3), 131-138. https://doi.org/10.1080/00220670309598801

Galante, A., \& Thomson, R. I. (2017). The effectiveness of drama as an instructional approach for the development of second language oral fluency, comprehensibility, and accentedness. TESOL Quarterly, 51(1), 115-142. https://doi.org/10.1002/tesq.290

Gomez, D. I. (2010). Using drama to improve oral skills in the ESL classroom. International Schools Journal, 30(1), 29-37.

Gulay, H., \& Akman, B. (2009). Social skills in preschool period (Okul öncesi dönemde sosyal beceriler). Ankara: Pegem Academy.

Heathcote, D. (1984). Dorothy Heathcote: Collected writings on education and drama. London; Hutchinson.

Hedges, L. V., \& Olkin, I. (1985). Statistical methods for meta analysis. USA: Academic Press Inc.

Hendrix, R., Eick C., \& Shannon, D. (2012). The integration of creative drama in an inquiry-based elementary program: The effect on student attitude and conceptual learning. Journal of Science Teacher Education, 23(7), 823-846. https://doi.org/10.1007/s10972-012-9292-1

Kaf, O. (2000). The effect of creative drama method in some social skills in life science course. Cukurova University Institute of Social Sciences, 6(6), 173-184.

Kao, S. M., \& O'Neill, C. (1998). Words into worlds: Learning a second language through process drama. Stamford: Ablex Publishing Corporation.

Kardas, M. N., \& Koc, R. (2017). Effect of drama instruction method on students' Turkish verbal skills and speech anxiety. International Journal of Progressive Education, 13(1), 64-78.

Kavcar, C., Oguzkan, F., \& Sever, S. (1999). Teaching Turkish. Ankara: Engin Publication’s.

Kaya, G. I. (2008). Effectiveness of creative drama method in Turkish lesson in the fourth grade of primary schools (Unpublished master's thesis). Ondokuz Mayis University, Samsun, Turkey.

Koc, N. (2009). The effect of drama in education on language development of six age's children (Unpublished master's thesis). Uludag University, Bursa, Turkey.

Kocayoruk, A. (2000). The Effect of drama on improving elemantary school student's social skills (Unpublished master's thesis). Ankara University, Ankara, Turkey.

Kortan, S. (2010). Effect of musical dramatization on empathy tendencies of secondary school students (Unpublished 
doctoral dissertation). Dokuz Eylul University, Izmir, Turkey.

Lee, B. K., Patall, E. A., Cawthon, S. W., \& Steingut, R. R. (2015). The effect of drama-based pedagogy on pre K-16 outcomes: A meta-analysis of research from 1985 to 2012. Review of Educational Research, 85(1), 3-49. https://doi.org/10.3102/0034654314540477

Littel, J. H., Corcoran, J., \& Pillai, V. (2008). Systematic reviews and meta-analyses. New York: Oxford University. https://doi.org/10.1093/acprof:oso/9780195326543.001.0001

Lynch, S. A., \& Simpson, C. G. (2010). Social skills: laying the foundation for success. Dimension of Early Childhood, $38(2), 3-12$.

Maden, S. (2010). The effectiveness of drama method on gaining basic language skills in primary school sixth class Turkish course (Love theme example) (Unpublished doctoral dissertation). Ataturk University, Erzurum, Turkey.

Mantas, S. (2014). The effect of drama activities on 4th grade primary school student's development of social skill and cooperation behaviors (Unpublished doctoral dissertation). Ataturk University, Erzurum, Turkey.

McNaughton, M. J. (2004). Educational drama in the teaching of education forsustain ability. Environmental Education Research, 10(2), 139-155. https://doi.org/10.1080/13504620242000198140

Onder, A. (2001). Educational drama for living learning: Practical techniques and examples based on theoretical background. Istanbul: Epsilon.

O'Neill, C., \& Lambert, A. (1991). Drama structures: A practical handbook for teachers. Portsmougth: Heinemann Educational Books.

Onemli, M., Totan, T., \& Abbasov, A. (2015). The contribution of creative drama tranining on social skill areas such as speaking and relationship building of the children with special needs. Asian Journal of Instruction, 3(1), 50-65.

Onur, H. O. (2016). Impact of usage of forum theatre technique in creative drama on developing communication skills of mothers (Unpublished master's thesis). Ankara University, Ankara, Turkey.

Ormanci, U., \& Ozcan, S. (2014). The effect of the using drama method in primary school science and technology courses on student attitude and motivation. Pegem Journal of Education and Instruction, 4(4), 23-40. https://doi.org/10.14527/pegegog.2014.020

Pigott, T. D. (2012). Advances in meta analysis. USA: Springer. https://doi.org/10.1007/978-1-4614-2278-5

Rinn, R. C., \& Markle, A. (1979). Modification of social skill deficits in children, In A. Beiaack \& M. Hersen (Eds.), Research and practice in social skills training (pp. 107-129). New York: Plenum Press. https://doi.org/10.1007/978-1-4899-2192-5_4

Samanci, O., \& Ucan, Z. (2017). Social skill education in children. Journal of Graduate School of Social Sciences, 21(1), 281-288.

Schulze, R. (2007). The State and the art of meta analysis. Zeitschrift für Psychologie/Journal of Psychology, 215(2), 87-89. https://doi.org/10.1027/0044-3409.215.2.87

Senol, O. E. N. (2011). The effect of creative drama practices in mathematics on primary school students' problem solving strategies, achievement, self-concept and interaction patterns (Unpublished doctoral dissertation). Dokuz Eylul University, Izmir, Turkey.

Sever, S. (2011). Turkish teaching and mastery learning. (Türkçe öğretimi ve tam öğrenme). Ankara: Ani Publishing.

Sorias, O. (1986). Social skills and evaluation methods. Journal of Psychology, 5(20), 25-26.

$\mathrm{Su}, \mathrm{B}$. A. (2010). An alternative technique for developing speaking skills in English language teaching: Creative drama (Unpulished master's thesis). Gaziosmanpasa University, Tokat, Turkey.

Tanriseven, I. (2000). Using dramatization as a problem solving strategy in mathematics. (Unpublished master's thesis). Marmara University, Istanbul, Turkey.

Taylor, K. (2000). Using drama as a tool for educating young people about accessing health services-a comparison of two approaches. Health Education, 100(4), 168-174. https://doi.org/10.1108/09654280010332340.

Thalheimer, W., \& Cook, S. (2002). How to calculate effect sizes from published research articles: A simplified methodology. Retrieved from http://work-learning.com/effect_sizes.htm.

Toraman, C., \& Ulubey, O. (2016). The effect of creative drama method on the attitude towards course: A Meta-analysis study. Journal of Educational Sciences Research, 6(1), 87-115. https://doi.org/10.12973/jesr.2016.61.5 
Turkish Language Association (2018). Skill Retrieved from http://www.tdk.gov.tr/index.php?option=com_gts\&arama=gts\&guid=TDK.GTS.5a94777cd54756.97704952

Ulas, A. H. (2008). Effects of creative, educational drama activities on developing oral skills in primary school children. American Journal of Applied Sciences, 5(7), 876-880. https://doi.org/10.3844/ajassp.2008.876.880

Ulubey, O., \& Gozutok, F. D. (2015). Future citizenship, democracy and human rights education with creative drama and other interactive teaching methods. Education \& Science, 40(182), 87-109. https://doi.org/10.15390/EB.2015.4845

Ulubey, O., \& Toraman, C. (2015). The effect of creative drama on students' academic achievement: A meta-analysis study. Mustafa Kemal University Journal of Social Sciences Institute, 12(32), 195-220.

Ustun, U., \& Eryilmaz, A. (2014). A research methodology to conduct effective research syntheses: Meta-analysis. Education and Science, 39(174), 1-32.

Ustundag, T. (1996). Three dimensions of creative drama. Journal of Education for Life, 19(95), 19-23.

Ustundag, T. (2010). Emotional intelligence, affective traits and creative drama and creative drama. In O. Adiguzel (Eds.), The creative drama is written in 1999-2002 (pp. 56-65). Ankara: Naturel.

Ustundag, T. (2014). Diary of my creative drama teacher (Yaratıcı drama ögretmenimin günlüğ̈̈). Ankara: Pegem Academy.

Walker, E. M., Tabone, C., \& Weltsek, G. (2011). When achievement data meet drama and arts integration. Language Arts, 88, 365-372.

Yagmur, E. (2010). Effect of 7th grade science and technology lesson supported with creative drama on critical thinking skill and success (Unpublished master's thesis). Sakarya University, Sakarya, Turkey.

Yigit, R., \& Yilmaz, H. (2011). Primary dducation II. examining the relationship between the level of social skills and self-esteem of the graduates. Ahmet Kelesoglu Education Faculty Journal, 31, 335-347.

Yilmaz, S. (2013). Effect of education with drama method in social studies on the levels of social ability, emphathic ability and academic achievement of students (Unpublished doctoral dissertation). Ataturk University, Erzurum, Turkey.

Appendix A

\section{Sampled Studies Used in Meta-analysis}

Akfirat, F. O. (2015). The impact of creative drama on the development of social skills of hearing impaired. Ankara University Faculty of Educational Sciences Journal of Special Education, 5(01), 9-22.

Akin, A. (2016). The usage of creative drama method in teaching foreign languages, impact on critical, reflective thinking skills and the attitude foreign language learning of 12. grade students in high school (Unpublished master's thesis). Adnan Menderes University, Aydin, Turkey.

Akyol, A. K., \& Hamamci, Z. (2007). The effect of drama education on the level of empathetic skills of university students. Bulgarian Journal of Science and Education Policy, 1(1), 205-215.

Aslan, E. (2008). The effect of drama based social skill education on social intercourse and cooperation behaviours of 6 years old children (Unpublished master's thesis). Adnan Menderes University, Aydin, Turkey.

Aslanel, O. (2011). Analysis of the effect of teaching of secondary education tenth grade language and expression lesson through creative drama method to the students? Course attitudes and improvement of their social skills (Unpublished master's thesis). Gazi University, Ankara, Turkey.

Aykac, M. (2011). The effect of creative drama activities on children's narration skills set up with child literature texts in Turkish teaching (Unpublished doctoral dissertation). Ankara University, Ankara, Turkey.

Aykac, M., \& Cetinkaya, G. (2013). The effect of creative drama activities on preservice Turkish language teachers' speaking skills. Electronic Turkish Studies, 8(9), 671-682.

Bagceci, E. (2015). Developing writing skills through drama in EFL classroom (Unpublished master thesis). Mugla Sitki Kocman University, Mugla, Turkey.

Cakmakci, E. (2009). Examination of the effect of drama lessons on 4th grade students of primary school when bringing in the abilities of decision making (Unpublished master's thesis). Eskisehir Osmangazi University, Eskisehir, Turkey.

Can, Y. M. (2009). A study on the effect of drama education on creative thinking skills of six-year-old preschool 
children (Unpublished doctoral dissertation). Ankara University, Ankara, Turkey.

Cetingoz, D., \& Gunhan, B. C. (2012). The effects of creative drama activities on social skills acquisition of children aged six. Cukurova University Faculty of Education Journal, 41(2), 54-66.

Comertpay, B. (2006). The effect of drama on acquisition of children aged 5-6 (Unpublished master's thesis). Cukurova University, Adana, Turkey.

De la Cruz, R. E., Lian, M. C. J., \& Morreau, L. E. (1998). The effects of creative drama on social and oral language skills of children with learning disabilities. Youth Theatre Journal, 12(1), 89-95. https://doi.org/10.1080/08929092.1998.10012498.

Erden, G. (2016). The effects of the techniques of drama and cooperative learning onreading-comprehension skills, retention and attitude of fifth grade students (Unpublished master's thesis). Abant Izzet Baysal University, Bolu, Turkey.

Erkan, G. \& Aykac, M. (2014). The effects of creative drama activities constructed with samed behrengi books on the writing skills and attitudes of students. The Journal of International Social Research, 7(31), 600-610.

Eti, I. (2010). The effects of drama activities on social skills of 5-6 years old children who enrolled in preschool institute (Unpublished master's thesis). Cukurova University, Adana, Turkey.

Freeman, G. D., Sullivan, K. \& Fulton, C. R. (2010). Effects of creative drama on self-concept, social skills, and problem behavior. The Journal of Educational Research, 96(3), 131-138. https://doi.org/10.1080/00220670309598801

Galante, A., \& Thomson, R. I. (2017). The effectiveness of drama as an instructional approach for the development of second language oral fluency, comprehensibility, and accentedness. TESOL Quarterly, 51(1), 115-142.

Gomez, D. I. (2010). Using drama to improve oral skills in the ESL classroom. International Schools Journal, 30(1), 29-37.

Gorgulu, F. (2009). Effects of drama ducation supported cooperative learning activities on the communication skills of 5-6 years old children (Unpublished master thesis). Adnan Menderes University, Aydin, Turkey.

Gundogdu, R., \& Izgar, H. (2010). Yaratıcı drama temelli çatışma çözme programının ergenlerin çatışma çözme becerisine etkisi. Selçuk Üniversitesi Ahmet Keleşoğlu Eğitim Fakültesi Dergisi, 30, 81-100.

Gurler, I. (2013). Effects of using dramatic text on developing self-confidence and pronunciation in the speaking course of 9th grade EFL students (Unpublished master's thesis). Ataturk University, Erzurum, Turkey.

Ihmeideh, F. (2015). The impact of dramatic play centre on promoting the development of children's early writing skills. European Early Childhood Education Research Journal, 23(2), 250-263. https://doi.org/10.1080/1350293X.2014.970848

Joronen, K., Konu, A., Rankin, H. S., \& Åstedt-Kurki, P. (2011). An evaluation of a drama program to enhance social relationships and anti-bullying at elementary school: A controlled study. Health Promotion International, 27(1), 5-14. https://doi.org/10.1093/heapro/dar012

Kaf, O. (2000). The effect of creative drama method in some social skills in life science course. Cukurova University Institute of Social Sciences, 6(6), 173-184.

Kahriman, M. (2014). The effect of drama method on empathy, communication skills and value sensations of the 3rd grade students (Unpublished master's thesis). Mustafa Kemal University, Hatay, Turkey.

Kara, Y., \& Cam, F. (2007). Effect of creative drama method on the reception of some social skills. Hacettepe University Journal of Education, 32, 145-155.

Karateke, E. (2006). The effects of creative drama on writing skills of 6th grade primary school students (Unpublished master's thesis). Mustafa Kemal University, Hatay, Turkey.

Kardas, M. N., \& Koc, R. (2017). Effect of drama instruction method on students' Turkish verbal skills and speech anxiety. International Journal of Progressive Education, 13(1), 64-78.

Kilic, S., \& Tuncel, M. (2009). The effects of creative drama on speaking English and attitudes towards speaking English. Abant Izzet Baysal University Journal of Faculty of Education, 9(2), 55-81.

Koc, N. (2009). The effect of drama in education on language development of six age's children (Unpublished master's thesis). Uludag University, Bursa, Turkey.

Kocayoruk, A. (2000). The Effect of drama on improving elemantary school student's social skills (Unpublished 
master's thesis). Ankara University, Ankara, Turkey.

Kortan, S. (2010). Effect of musical dramatization on empathy tendencies of secondary school students (Unpublished doctoral dissertation). Dokuz Eylul University, Izmir, Turkey.

Koseoglu, I. (2006). Using dramatization as a problem solving strategy in geographein (Unpublished master's thesis). Marmara University, Istanbul, Turkey.

Laurin, S. (2010). The effect of story drama on children's writing skills (Unpublished doctoral dissertation). Concordia University, Montreal, Canada.

Maden, S. (2010). The effectiveness of drama method on gaining basic language skills in primary school sixth class Turkish course (Love theme example) (Unpublished doctoral dissertation). Ataturk University, Erzurum, Turkey.

Mutlu Aydin, S. (2013). The effect of the drama activities that is done in grade 4th on students' problem solving abilities in Turkey (Unpublished master's thesis). Ataturk University, Erzurum, Turkey.

Onemli, M., Totan, T. \& Abbasov, A. (2015). The contribution of creative drama tranining on social skill areas such as speaking and relationship building of the children with special needs. Asian Journal of Instruction, 3(1), 50-65.

Onur, H. O. (2016). Impact of usage of forum theatre technique in creative drama on developing communication skills of mothers (Unpublished master's thesis). Ankara University, Ankara, Turkey.

Ozcan, S. (2013). Effect of the creative drama on the development of conceptual narrative skills (Unpublished master's thesis). Gazi University, Ankara, Turkey.

Paksoy, E. (2008). The effects of process drama on enhancement of self-esteem and oral skills in English language classroom (Unpublished master's thesis). Cukurova University, Adana, Turkey.

Pekdogan, S., \& Korkmaz, H. İ. (2016). An experimental study on development critical thinking skills via educational drama as a teaching method. International Online Journal of Educational Sciences, 8(3), 12-21.

Rose, D. S., Parks, M., Androes, K., \& McMahon, S. D. (2000). Imagery-based learning: Improving elementary students' reading comprehension with drama techniques. The Journal of Educational Research, 94(1), 55-63. https://doi.org/10.1080/00220670009598742

Sever, Ö. (2010). The effects of creative drama on acquisition of the attainments of musical creativity learning domain in third grade music lessons in primary education (Unpublished master's thesis). Abant Izzet Baysal University, Bolu, Turkey.

Su Bergil, A. (2010). An alternative technique for developing speaking skills in English language teaching: Creative drama (Unpulished master's thesis). Gaziosmanpasa University, Tokat, Turkey.

Tanriseven, I. (2000). Using dramatization as a problem solving strategy in mathematics. (Unpublished master's thesis). Marmara University, Istanbul, Turkey.

Tedik, G. (2013). Using dramatization as a problem solving strategy in mathematics (Unpublished master's thesis). Ataturk University, Erzurum, Turkey.

Ulas, A. H. (2008). Effects of creative, educational drama activities on developing oral skills in primary school children. American Journal of Applied Sciences, 5(7), 876-880.

Yagmur, E. (2010). Effect of 7th grade science and techology lesson supported with creative drama on critical thinking skill and success (Unpublished master's thesis). Sakarya University, Sakarya, Turkey.

Yavuzer, Y. (2012). Effect of Creative drama-based group guidance on male-adolescents' conflict resolution skills. Eurasian Journal of Educational Research, 47, 113-130.

Yilmaz, S. (2013). Effect of education with drama method in social studies on the levels of social ability, emphathic ability and academic achievement of students (Unpublished doctoral dissertation). Ataturk University, Erzurum, Turkey.

\section{Copyrights}

Copyright for this article is retained by the author(s), with first publication rights granted to the journal.

This is an open-access article distributed under the terms and conditions of the Creative Commons Attribution license which permits unrestricted use, distribution, and reproduction in any medium, provided the original work is properly cited. 